\title{
KECENDERUNGAN GLOBAL PENDIDIKAN TINGGI DAN PERGESERAN PARADIGMA REFORMASI PENDIDIDIKAN TINGGI PADA \INSTITUSI PENDIDIKAN TINGGI KEAGAMAAN ISLAM
}

\author{
Ahmad Syamsul Arifin \\ Prodi PAI STIA Alma Ata Yogyakarta \\ Email: houseofhappiness@gmail.com
}

\begin{abstract}
Massifikation impact of globalization and the phenomenon has changed the global trend of higher education around the world over the past decades. The global trend include: globalization and internaionalisasi, access and equity, private higher education and privatization, quality assurance framework, accountability and qualifications, financing higher education, centralization and crisis of academic profession, experience of students, teaching, learning and assessment, information technology communication and distance education, research, university-industry linkages. The global trend is also creating a number of opportunities and challenges for institutions of higher education. More juah, the global trend is also belped provide a significant impact to the paradigm shift in institutional reform of bigher education, including higher education which includes the Islamic religious dimension of globalization, localization, and individualization.
\end{abstract}

Keywords: global trends, Higher Education, Higher Education Islamic Religious

\section{PENDAHULUAN}

Pusat Data dan Analisa (PDA) majalah Tempo pada tahun 2007 pernah menyelenggarakan survei tentang persepsi masyarakat terhadap perguruan tinggi di Indonesia. Hasilnya, dari sekian banyak Pendidikan Tinggi Keagamaan Islam (PTKI) yang ada di Indonesia, hanya Universitas Islam Indonesia (UII) yang berhasil menembus urutan ke-8 PTS terfavorit di Indonesia. Berdasarkan hasil survei PDA majalah Tempo tersebut tidak ada satupun PTKIN baik dari UIN, IAIN ataupun STAIN yang masuk top of mind terfavorit. ${ }^{1}$ Lebih lanjut, setahun berikutnya, tepatnya pada edisi Februari 2008, Majalah "Globe Asia" merilis data hasil survei dan pemeringkatan 10 Perguruan Tinggi Terbaik di

1“10 Universitas Terbaik”, Edisi Khusus Perguruan Tinggi/Infografik, Majalah Tempo edisi 20 Mei 2007. 
Indonesia versi majalah tersebut, dan hasilnya, untuk kategori PTS, hanya Univesitas Muhammadiyah Malang (UMM) yang berhasil meringsek naik ke peringkat ke-7 PTS terbaik di Indonesia. Sedangkan untuk kategori 10 PTN terbaik, tidak ada satu pun PTKIN yang masuk dalam kategori tersebut. ${ }^{2}$

Berdasarkan ilustrasi tersebut, setidaknya kita dapat membayangkan bagaiamana kondisi dan kualitas PTKI saat ini. Hingga saat ini, setidaknya terdapat 681 lembaga Pendidikan Tinggi Kegamaan Islam, baik negeri maupun swasta, dengan total program studi (prodi) sebanyak1430 prodi. Dari seluruh jumlah total program studi tersebut, hampir sebagian besarnya telah terkareditasi (lihat Gambar 1). Meskipun demikian, berdasarkan Angka Partispasi Kasar (APK) pendidikan tinggi pada tahun 2012-2013, yakni sekitar $28,6 \%$, PTKI hanya menyumbang sebesar $2,9 \%{ }^{3} \mathrm{Hal}$ ini tentu saja sangat ironis jika dibandingkan prosentase perkembangan PTKI di Indonesia, yang pada tahun 2011 ditaksir telah mencapai $6,7 \% .^{4}$
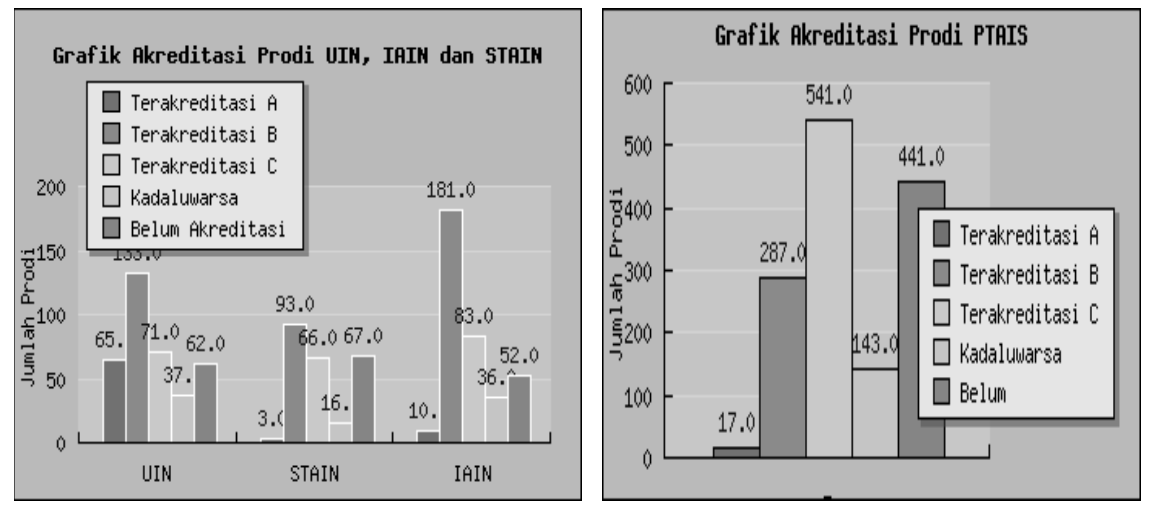

Gambar 1. Grafik Akreditasi Progrm Studi PTKIN dan PTAIS

Sumber: wwre.ranking-ptai.info

"'Peringkat PTN", Edisi Jumat, 30 Mei 2008 http://nasional.kompas.com/ $\mathrm{read} / 2008 / 05 / 30 / 05101132 /$ peringkat.ptn diakses 27 November 2014

${ }^{3}$ Bidang Pendayagunaan dan Pelayanan Data dan Statistik Pendidikan, APK/APM (Angka Partisipasi Kasar/Angka Partisipasi Murni) Tabun 2012/2013, Jakarta: Pusat Data dan Statistik Pendidikan, Kemdikbud, 2013), 5.

4“Sebaran Lembaga, Fakultas dan Prodi pada PTKIN dan PTAIS”, http://rankingptai.info diakses tanggal 10 September 2014 
Tabel 1. Angka Partisipasi Kasar Perguruan Tinggi Tahun 2012-2013

\begin{tabular}{|c|c|c|c|c|c|c|c|c|c|}
\hline No & Nama Provinsi & \begin{tabular}{c|} 
Penduduk usia \\
$19-23$ \\
\end{tabular} & PTN & PTS & KEDINASAN & PTAI & PTA (Non-Islam) & Jumlah Total & APK \\
\hline 1 & DKI Jakarta * & $1,041,486$ & 533,626 & 426,055 & 64,202 & 10,141 & 2,898 & $1,036,922$ & 99.56 \\
\hline 2 & Jawa Barat & $\overline{3}, 879,995$ & 125,189 & $484, \overline{494}$ & $11, \overline{7} \overline{7}$ & $41,55 \overline{3}$ & $-\frac{127}{127}$ & 663,110 & 17.09 \\
\hline 3 & Jawa Tengah & $2,509,182$ & 109,809 & 260,498 & 4,635 & 54,569 & 1,830 & 431,341 & 17.19 \\
\hline 4 & DI Yogyakarta & 328,585 & 72,723 & $\overline{145}, \overline{249}$ & 3,930 & 20,662 & - & $242, \overline{564}$ & 73.82 \\
\hline 5 & Jawa Timur & $\overline{2}, \overline{942}, \overline{546}$ & 159,982 & 488,912 & $\overline{9}, \overline{962}$ & $1 \overline{47}, \overline{548}$ & 315 & 806,719 & 27.42 \\
\hline$\sqrt{6}$ & Aceh & 469,533 & $43, \overline{725}$ & $\overline{119}, \overline{717}$ & $\overline{-}$ & 35,936 & $\overline{-}$ & 199,378 & $\overline{42 . \overline{46}}$ \\
\hline 7 & Sumatera Utara & $\overline{1}, \overline{198}, \overline{798}$ & $5 \overline{2}, \overline{8} 8 \overline{6}$ & 306,408 & $-\overline{2}, \overline{521}$ & $28, \overline{434}$ & $4, \overline{109}$ & 394,358 & 32.90 \\
\hline 8 & Sumatera Barat & $-\overline{403,970}$ & $-65, \overline{7} \overline{3}$ & 87,493 & $\overline{1,024}$ & 33,587 & $-\div$ & 187,877 & $\overline{46.51}$ \\
\hline 9 & Riau & $539, \overline{493}$ & 34,337 & $7 \overline{177}$ & $\because-ー-1$ & $-\overline{27}, \overline{322}$ & $=$ & 138,836 & $\overline{25.73}$ \\
\hline 10 & Jambi & 296,013 & $13, \overline{216}$ & $32, \overline{545}$ & - & $19, \overline{147}$ & 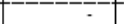 & 64,908 & $\overline{21.93}$ \\
\hline 11 & Sumatera Selatan & 755,832 & 29,493 & 130,632 & 91 & 13,467 & 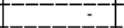 & $\overline{173}, \overline{683}$ & 22.98 \\
\hline 12 & Lampung & 692,765 & 28,236 & 78,491 & 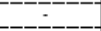 & 19,177 & 371 & 126,275 & 18.23 \\
\hline 13 & Kalimantan Barat & $\overline{417}, \overline{476}$ & 20,915 & 41,580 & $\overline{-}$ & 6,882 & $1, \overline{6} 62$ & 71,039 & $17 . \overline{17}$ \\
\hline 14 & Kalimantan Tengah & $\overline{219} \overline{492}$ & 9,298 & $16, \overline{8 B 3}$ & $=$ & $4, \overline{484}$ & 1,332 & 31,997 & $1 \overline{14.58}$ \\
\hline 15 & Kalimantan Selatan & 346,997 & 19,234 & 58,381 & 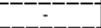 & 15,752 & $-\div$ & 93,367 & $\overline{26.91}$ \\
\hline 16 & Kalimantan Timur & $\overline{338}, \overline{164}$ & 39,621 & 40,519 & 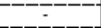 & $-\overline{6,565}$ & - & 86,705 & $25.6 \overline{4}$ \\
\hline 17 & Sulawesi Utara & 181,744 & 29,469 & 25,917 & $\overline{265}$ & $\overline{3}, \overline{054}$ & 1,020 & 59,725 & 32.86 \\
\hline 18 & Sulawesi Tengah & 231,029 & 15,539 & 48,041 & $=$ & $6, \overline{671}$ & 199 & 70,450 & 30.49 \\
\hline 19 & Sulawesi Selatan & $\overline{736}, \overline{918}$ & $5 \overline{7}, \overline{199}$ & 255,543 & 2,091 & 36,258 & $\overline{2}, \overline{366}$ & $-\overline{353}, \overline{457}$ & $\overline{47.96}$ \\
\hline 20 & Sulawesi Tenggara & 211,553 & 16,819 & $49, \overline{424}$ & --ー-十 & $\overline{5}, \overline{167}$ & -1 & $71, \overline{410}$ & 33.76 \\
\hline 21 & Maluku & 137,230 & $24, \overline{312}$ & 23,833 & 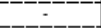 & $7, \overline{568}$ & $2, \overline{197}$ & $57, \overline{9} 10$ & 42.20 \\
\hline 22 & Bali & 296,042 & 29,636 & 48,872 & 799 & 305 & 7,859 & 87,471 & 29.55 \\
\hline 23 & Nusa Tenggara Barat & 419,649 & $17,37 \overline{2}$ & 93,042 & 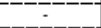 & 15,992 & $-\frac{452}{4}$ & 126,858 & 30.23 \\
\hline 24 & Nusa Tenggara Timur & 373,934 & 20,804 & 47,344 & - & $\because--$ & 8,252 & 76,400 & 20.43 \\
\hline 25 & Papua & 277,555 & 18,498 & 29,424 & - & 898 & 1,128 & 49,948 & $\overline{18.00}$ \\
\hline 26 & Bengkulu & 167,900 & 12,652 & 34,603 & $\because$ & $\overline{8}, \overline{950}$ & -- & 56,205 & $\overline{33.48}$ \\
\hline 27 & Maluku Utara & $96, \overline{450}$ & $-\overline{6}, \overline{597}$ & $19, \overline{985}$ & $\because$ & $2, \overline{786}$ & 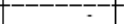 & 29,368 & 30.45 \\
\hline 28 & Banten & $1,095,580$ & 12,631 & 91,865 & $-\overline{1,457}$ & 34,462 & 460 & 140,875 & 12.86 \\
\hline 29 & Bangka Belitung & $-\overline{12} \overline{3}, 78 \overline{3}$ & $-\overline{2}, 051$ & $\overline{6}, \overline{8} 25$ & $\div-$ & $\overline{1}, \overline{450}$ & - & $10, \overline{326}$ & $-\overline{8.34}$ \\
\hline 30 & Gorontalo & 87,408 & $16, \overline{961}$ & $15, \overline{302}$ & - & $\overline{2}, \overline{914}$ & - & $35, \overline{177}$ & $40.2 \overline{4}$ \\
\hline 31 & Kepulauan Riau & 188,517 & $\overline{6}, \overline{271}$ & 25,782 & 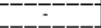 & $2, \overline{303}$ & - & $-\overline{34}, \overline{356}$ & $\overline{18.22}$ \\
\hline 32 & Papua Barat & 79,511 & 4,393 & 15,079 & 348 & $\overline{1}, \overline{004}$ & $-\overline{69}$ & 20,893 & 26.28 \\
\hline & Sulawesi Barat & $\overline{100,170}$ & & $\overline{19}, \overline{954} \overline{4}$ & - & $\overline{2}, \overline{192}$ & $\because+$ & 22,146 & $\overline{22.11}$ \\
\hline & Indonesia & $21,185,300$ & $1,649,267$ & $3,645,869$ & 103,072 & 617,200 & \begin{tabular}{|l|}
36,646 \\
\end{tabular} & $6,052,054$ & 28.57 \\
\hline
\end{tabular}

Kenyataan tersebut menegaskan bahwa hingga saat ini masih banyak persoalan sekaligus tantangan besar yang masih dihadapi oleh PTKI. Persoalan yang dialami oleh PTKI sangatlah kompleks, tidak hanya sekedar persoalan infrastruktur dan manajerial semata, melainkan juga persoalan fundametal lain.

Penataan kembali Pendidikan Tinggi Kegamaan Islam mutlak dilakukan. Sebagaimana dinyatakan dalam dokumen World Declaration on Higher Education for the Treenty-First Century: Vision and Action oleh UNESCO, yang menyatakan bahwa perubahan visi dan paradigma baru perguruan tinggi mutlak diperlukan di tengahtengah kondisi perubahan tatanan global yang cepat. ${ }^{5}$ Penataan tersebut menuntut adanya penjaminan keefektifitasan kebijakan, transparansi, dan akuntabilitas penyelenggaran pendidikan. Melalui upaya ini, Perguruan Tinggi Keagamaan Islam diharapkan dapat melayani kebutuhan yang lebih beragam melalui kandungan pendidikan (contents), metode, dan penyampaian pendidikan yang beragam dan disandarkan pada jenis dan bentuk-bentuk baru hubungan dengan masyarakat dan sektor-sektor masyarakat global secara lebih luas serta meningkatkan peran dan daya saing PTKI pada tatanan masyarakat global.

${ }^{5}$ lihat, UNESCO, Higher Education in the Twenty-First Century: Vision and Action (Paris: UNESCO, 1998) 


\section{KECENDERUNGAN GLOBAL PADA PENDIDIKAN TINGGI DI ERA GLOBAL}

Albacth et al. (2009) dalam bukunya yang berjudul Trends in Global Higher Education; Tracking an Academic Revolution (A Report Prepare For UNESCO 2009 World Conference on Higher Education) menyebutkan bahwa sejak konferensi dunia UNESCO tentang Higher Education (HE) di tahun 1998 hingga sekarang setidaknya muncul sejumlah kecenderungan dan isu-isu global yang menjadi bahan diskusi pada beberapa dekade terakir yang telah memberikan dampak yang cukup besar bagi proses tranformasi dan reformasi pendidikan tinggi di seluruh dunia. ${ }^{6}$

\section{Globalisasi dan Internasionalisasi}

Globalisasi merujuk pada sejumlah proses yang menjadikan negaranegara menjadi terintegrasi melalui perdagangan barang, modal, pekerja dan gagasan. ${ }^{7}$ Proses ini telah menciptakan sebuah tatanan konsep multidimensional yang menjadikan aspek-aspek sosial, budaya, teknologi, politik dan ideologi menjadi semakin homogen, dan setiap negara memiliki ketergantungan yang besar terhadap pertumbuhan ekonomi yang didorong oleh prinsipprinsip pasar bebas. ${ }^{8}$ Globalisasi telah menciptakan egalitarianisme dalam bidang sosial, memicu munculnya internasionalisasi budaya, menciptakan saling ketergantungan dalam proses produksi dan pemasaran dalam bidang

${ }^{6}$ Altbach, Philip G., et al , Higher Education; Tracking an Academic Revolution (A Report Prepare For UNESCO 2009 World Conference on Higher Education) .(Paris, UNESCO: 2009), iii-xxi

${ }^{7}$ Istilah "Globalisasi”memiliki pengertian yang sangat luas. Sejumlah definisi terkait istilah "Globalisasi" diberikan oleh sejumlah ahli. Wallerstein (1988) memberikan definisi globalisasi sebagai sebuah sistem kapitalis dunia. Deepak Nayyar (2006) mendefinisikan istilah globalisasi sebagai sebuah proses pengintegrasian ekonomi dunia. Giddens (2000) mendefinisikannya sebagai peningkatan interdependensi bangsa-bangsa dalam aspek sosial, politik dan Steger (2003) mendefinisikan istilah globalisasi sebagai sebuah konsep multidimensional yang menggambarkan sebuah interdependensi yang mendalam, sedangkan Harvey (2003) menyamakannya dengan sebuah filosofi neo-liberal. Rangkuman definisi tersebut dapat dilihat dalam F. Maringe, "The Meanings of Globalization and Internationalization in HE: Findings from a World Survey" dalam Globalization and Internationalization in Higher Education: Theoretical, Strategic and Management Perspectives,ed. Maringe et al. (New Yok: Continuum International Publishing Group, 2010), 23-24.

${ }^{8}$ F. Maringe. "The Meanings of Globalization and Internationalization in HE: Findings from a World Survey" dalam Globalization and Internationalization in Higher Education: Theoretical, Strategic and Management Perspectives, ed. Maringe et al. (New Yok: Continuum International Publishing Group, 2010), 24. 
ekonomi, dan menciptakan liberalisasi dalam bidang politik. ${ }^{9}$ Globalisasi juga telah menyebabkan terbentuknya pola dan dimensi baru yang identik dengan mulai memudarnya batas-batas negara, menyempitnya ruang dan waktu, serta menjadikan dunia tanpa batas (borderless). Setiap negara akan masuk dalam pusaran persaingan seluruh aspek dinamika dunia. Globalisasi juga ditandai oleh semakin ketatnya persaingan antar negara di berbagai bidang.

Sedangkan internasionalisasi pendidikan merupakan serangkaian dimensi dan aspek dari seluruh aktivitas dan strategi - baik sektoral, nasional, dan institusional - yang didesain untuk menggabungkan sistem pendidikan internasional ke dalam sistem pendidikan yang ada. Internasionalisasi perguruan tinggi (HE) pada level nasional, sektoral dan institusional merupakan sebuah proses pengintegrasian dimensi internasional, inter-kurtural, atau global ke dalam tujuan, fungsi atau penyelenggaran pendidikan tinggi. Fokus internasionaliasi pendidikan tinggi terkait pada persoalan bagaiamana meningkatkan kualitas perguruan tinggi dalam persaingan pasar tenaga kerja global serta bagaiman mengukur kualitas tersebut. Kebijakan Internasionalisasi pendidikan tinggi berkisar pada program studi luar negeri yang memungkinkan mahasiswa belajar tentang budaya lain, menyediakan akses pendidikan tinggi di sejumlah negara, serta aktivitas lain untuk meningkatkan perspektif dan ketrampilan internasional mahasiswa, meningkatkan program bahasa asing dan memberikan pemahaman lintas budaya.

Lebih lanjut, bentuk kerjasama dan kemitraannya diarahkan pada pengembangan untuk mengurangi resiko, meningkatkan daya saing, meningkatkan citra dan memperluas basis ilmu pengetahuan untuk penelitian dan pendidikan. Untuk mewujudkan sistem pendidikan tinggi internasional, dibutuhkan sebuah sistem universal yang dapat memudahkan terjadinya pertukaran informasi dan pelajar. ${ }^{10}$

Menurut Knight, internasionalisasi pendidikan, dalam konteks globalisasi, merupakan reaksi terhadap kekuatan global, namun pada saat yang bersamaan juga sebagai agen dari globaliasi itu sendiri. ${ }^{11}$ Dengan demikian, internasionalisasi pendidikan dan globalisasi merupakan satu kesatuan layaknya dua sisi mata uang yang tidak dapat dipisahkan.

Bagi sebagian pihak, globalisasi dan internasionalisasi pendidikan tinggi ini telah menawarkan sejumlah peluang baru untuk belajar dan melakukan penelitian tanpa dibatasi lagi batas-batas nasional (national boundaries). Namun bagi

\section{${ }^{9}$ Ibid.}

${ }^{10}$ Ibid., 26

${ }^{11} \mathrm{~J}$. Knight, "Internationalisation of Higher Education." dalam Organisation for Economic Cooperation and Development, Quality and Internationalisation in Higher Education, (Paris: OECD, 1999), 14. 
sebagian lain, globalisasi dan internasionalisasi pendidikan tinggi dianggap sebagai "serangan" terhadap budaya dan ototnomi nasional. Tidak dapat diragukan lagi, globalisasi dan internasionalisasi pendidikan tinggi telah memberikan dampak yang luar biasa bagi universitas-universitas di seluruh belahan dunia. Setidaknya 2,5 juta lebih pelajar, ribuan sarjana - dari berbagai disiplin ilmu - dan universitas telah melakukan ekspansi secara bebas ke berbagai penjuru dunia dan menjalin ribuan perjanjian kesepakatan dan kerjasama. ${ }^{12}$

\section{Akses dan Keadilan}

Persoalan kemudahan dan keadilan dalam akses pendidikan bagi setiap orang merupakan salah satu topik utama yang selalu didengungkan dalam Konferensi Pendidikan Tinggi Dunia sejak konferensi itu pertama kali diselenggarakan yakni di tahun 1998. Dalam bentuk yang sederhana, akses yang lebih besar pada pendidikan tinggi diartikan sebagai pemberian kemungkinan yang lebih besar bagi setiap orang untuk mendapatkan kesempatan belajar di perguruan tinggi. Sejumlah penelitian telah menunjukkan bahwa persoalan kemudahan dan persamaan dalam akses pendidikan tinggi dipengaruhi oleh berbagai variabel. Namun setidaknya para peneliti sepakat bahwa pemberian akses yang sama bagi setiap orang - dalam arti yang sebenar-benarnya - berarti mengatasi persoalan ketidakadilan dan kesenjangan sosial-ekonomi antar bangsa di dunia. ${ }^{13}$

Gorard et. Al (2006) mengutip sebuah laporan Dewan Pendanaan Pendidikan Tinggi Inggris menyatakan bahwa:

Inequalities in higher education participation are evident throughout the life course and include differences in terms of time (and age), place, gender, ethnicity, first language, parental (and sibling) social class, parental education, type of school attended, housing tenure, health/ disability, criminal activity, learning difficulties, family structure and religious background. Multiple social disadvantages can result in initial education and, subsequently, participation in other forms of learning. Parental income and education are particularly influential. Occupational status and family size are also relevant ... Quality of life factors (such as infant health) are important for understanding disengagement from education rather than participation within it.... The question is raised as to whether policymakers should seek to reduce inequality in education directly, or seek to reduce the wider inequalities that are reflected in education.

${ }^{12}$ Altbach, Philip G., et al , Higher Education; Tracking an Academic Revolution ..., v

${ }^{13}$ Gorard, S., Smith, E., May, H.,Thomas, L.,Adnett, N. and Slack, K. 2006. Review of Widening Participation Research: Addressing the Barriers to Participation in Higher Education. Diakses dari: http://www.hefce.ac.uk/pubs/RDreports/2006/rd13_06/ pada 1 mei 2009. 
Berdasarkan laporan tersebut, persoalan kesenjangan akses pendidikan dipengaruhi oleh sejumlah hal antara lain perbedaan waktu (usia), tempat, jenis kelamin, etnis, bahasa ibu, orang tua (saudara), kelas sosial, pendidikan orang tua, jenis sekolah yang didatangi, kesehatan/cacat, aktivitas kriminal, kesulitan belajar, struktur keluarga dan agama. Persoalan-persoalan sosial dan ekonomi tersebut akan mempengaruhi pendidikan awal hingga aktivitas partisipatif lain dalam hal aktivitas pembelajaran lainnya.

Sejumlah negara telah mengambil langkah-langkah krusial untuk mengentaskan persoalan akses pendidikan ini; Kementerian Pendidikan Meksiko, misalnya, telah melakukan investasi besar-besarkan untuk menambah layanan pendidikan pada daerah-daerah yang kurang "beruntung". Hasilnya, sekitar $90 \%$ dari jumlah mahasiswa yang masuk perguruan tinggi merupakan anak pertama dari setiap keluarga di wilayah tersebut, dan 40\% diantaranya tinggal di wilayah kumuh. Pemerintah Ghana, Kenya, Uganda, dan Republik Tanzania juga telah mampu meningkatkan partisipasi perempuan pada pendidikan tinggi. Pemerintah India juga membuat kebijakan untuk mewajibkan tiap universitas menyediakan satu ruangan kuliah bagi masyarakat "kasta rendah". Begitu pula halnya dengan dewan legislatif Brasil yang mewajibkan tiap universitas untuk menyediakan ruang kuliah bagi calon mahasiswa yang cacat dan Afro-Brazilia. ${ }^{14}$

\section{Pendidikan Tinggi Swasta dan Privatisasi}

Pertumbuhan pendidikan tinggi swasta di seluruh dunia telah mengalami peningkatan yang luar biasa beberapa dekade terakhir. Bahkan pendidikan tinggi swasta di beberapa negara Asis Timur, seperti Jepang, Republik Korea dan Filipina telah menjadi kekuatan dominan di negara-negara tersebut. Pendidikan tinggi swasta di sejumlah negara telah menjadi destinasi favorit bagi hampir separuh populasi di negar-negara seperti Meksiko, Brazil dan Chili. Pendidikan tinggi swasta telah mengalami perkembangan yang cukup pesat di Eropa Tengah dan Timur, beberapa negara pecahan Uni Soviet dan Afrika. Perkembangan yang signifikan juga terjadi di Cina dan India. ${ }^{15}$

Kecenderungan lain yang terjadi adalah privatisasi perguruan tinggi negeri. Sejumlah negara-negara besar telah mengurangi proporsi subsidi negara untuk perguruan tinggi negeri. Akibatnya, sejumlah universitas mencari dana tambahan dari sumber pendanaan lain. Biaya pendidikan mahasiswa menjadi sumber pendapatan terbesar. Sumber-sumber pendapatan lain diantaranya

\footnotetext{
${ }^{14}$ Altbach, Philip G., et al , Higher Education; Tracking an Academic Revolution ...,viii

${ }^{15}$ Ibid., xiv
} 
dana hibah penelitian, penjualan produk-produk universitas, jasa konsultasi dan penelitian, kerjasama universitas dan perusahaan. Pada beberapa kasus, penciptaan sumber pendanaan ini acapkali menciptakan konflik-konflik tersendiri dengan peran-peran lama institusi pendidikan dan telah turut berkontribusi atas komersialisasi institusi.

\section{Kerangka Kerja Penjaminan Mutu, Akuntabilitas dan Kualifikasi}

Penjaminan mutu pendidikan tinggi telah menjadi salah satu agenda utama kebijakan pendidikan di sejumlah negara. Sebagian negara masih berkutat dengn tahap awal desain dan implementasi aktivitas penjaminan mutu - pendirian lembaga, menetapkan standard, prosedur dan penjadwalan. Namun pada beberapa universitas di sejumlah negara telah mulai beralih pada tahapan yang lebih komplek, mereka mulai bergulat dengan isu-isu yang lebih "dalam" dan kompleks terkait persoalan penjaminan mutu di pendidikan tinggi.

Dari satu dekade ke dekade selanjutnya, pemahaman tentang kualitas terus mengalami pergeseran dan terus beradaptasi dengan perubahan konteks dan urgensi. Berdasarkan hasil konferensi UNESCO 1998 telah disebutkan bahwa:

Quality in higher education is a multidimensional concept, which should embrace all its functions, and activities;; teaching and academic programmes, research and scholarship, staffing, students, buildings, facilities, equipments, services to the community, and academic environment. ${ }^{16}$

Namun pada dekade selanjutnya, pemahaman tentang definisi kualitas diperbaharui ulang dalam laporan Konverensi UNESCO-CEPES dengan lebih merefleksikan penambahan tingkat kompeksitas lingkungan pendidikan pada pendidikan tinggi.

Quality in higher education is a multi-dimensional, multi-level, and dynamic concept that relates to the contextual settings of an educational model, to the institutional mission and objectives, as well as to the specific standards within a given system, institution, programme, or discipline. ${ }^{17}$

Keanekaragaman (diversity) telah menciptakan lingkungan pendidikan, mahasiswa, dan peluang yang beranekaragam. Di lain pihak, keanekaragaman tersebut juga menghadirkan tantangan yang lebih besar bagi universitas untuk

\footnotetext{
${ }^{16}$ van Ginkel, H.J.A. and Rodrigues Dias, M.A. Institutional and politicalchallenges of accreditation at the international level. J. Tres (ed.), Higher Education in the World 2007, (New York: Palgrave Macmillan, 2007), 39.

${ }^{17}$ Altbach, Philip G., et al , Higher Education; Tracking an Academic Revolution ..., 4
} 
menetapkan standar atau tolak ukur yang tepat untuk dapat diperbandingkan dengan institusi lain atau negara lain.

\section{Pembiayaan Pendidikan Tinggi}

Isu tentang pembiayaan pendidikan tinggi pada dekade awal abad 21 didominasi oleh dua fenomena. Pertama, peran pendidikan yang semakin penting untuk perjuangan ekonomi, individu, dan masyarakat bagi terciptanya demokrasi dan keadilan sosial. Kedua, peningkatan pembiayaan pendidikan secara signifikan. Massifikasi, yang didorong oleh demografis dan tingginya persentase minat para pelajar untuk melanjutkan ke pendidikan tinggi, telah menaikkan tekanan bagi pembiayaan untuk kegiatan pengajaran dan penelitian. Tekanan pembiayaan pembiayaan tersebut semakin tumbuh melebihi daya ekoniomi masyarakat.

Kondisi ini kemudian diperparah dengan adanya krisis ekonomi global yang melanda dunia. Situasi ini ditandai dengan melambatnya pertumbuhan ekonomi di negara-negara berkembang akibat dipengaruhi gejolak ekonomi yang terjadi di negara-negara maju. Dampak krisis ini akan mempengaruhi kemampuan tiap pemerintahan pada seluruh negara-negara di dunia untuk memenuhi alokasi kebutuhan dan pembiayaan di bidang pendidikan, kesehatan dan kesetaraan gender. ${ }^{18}$ Meskipun level, kondisi dan situasi serta durasi yang dihasilkan dari dampak krisis global ini variatif dari satu negara ke negara lain, namun setidaknya setiap lembaga pendidikan tinggi turut merasakan dampak negatif dari perkembangan ini.

\section{Sentralisasi dan Krisis Profesi Akademik}

Persaingan ketat antara permintaan penambahan kuota mahasiswa yang dapat melanjutkan dan mendaftarkan diri ke pendidikan tinggi (enrolment demand), pembatasan anggaran serta akuntabilitas yang lebih besar telah menciptakan suatu kondisi lingkungan yang kurang menguntungkan bagi profesi akademik di seluruh dunia. Tidak ada universitas yang dapat mencapai kesuksesan tanpa didukung oleh staf pengajar yang well-qualified dan memiliki komitmen tinggi. Kampus yang hebat maupun kurikulum yang inovatif tidak akan ada artinya tanpa didukung oleh tenaga pengajar (baca: profesor) yang hebat.

Sekarang ini ada kecenderungan bahwa pendidikan tinggi di seluruh dunia lebih menekankan pada pembangunan fisik daripada lebih berfokus pada persoalan software - orang-orang yang dapat menjadikan institusi pendidikan

\footnotetext{
${ }^{18}$ Ibid., 67-77
} 
mencapai kesuksesan. Di banyak negara, setengah atau lebih dari profesorprofesor yang ada semakin mendekati masa pensiun. Di pihak lain, jumlah guru besar "muda" yang dihasilkan untuk menggantikan tempat dari para profesor "senja" tersebut masih sangat sedikit, dan tidak jarang pula sebagian dari doktor-doktor yang ada lebih memilih untuk bekerja di luar bidang akademik.

Persoalan ini tentu dapat menghambat proses percepatan dan pengembangan pendidikan tinggi di seluruh dunia. Vietnam, misalnya, setiap tahun setidaknya membutuhkan tidak kurang dari 12.000 orang akademisi, namun hanya $10 \%$ dari profesi akademik ini yang memegang gelar doktor. ${ }^{19}$

Tantangan terkait isu profesi akademik ini sanagatlah kompleks. Sebagian dari persoalan tersebut terkait langsung dengan persoalan sistem dan kebijakan pendidikan tinggi, keungan dan atau persoalan-persoalan lain yang tercipta sebagai dampak persoalan masifikasi. Langkah-langkah yang tepat perlu untuk dilakukan mengatasi persoalan profesi akademik ini, yang sekaligus juga dapat memperbaiki capaian kesuksesan dari pendidikan tinggi. Perluasan kesempatan untuk studi dan mendapatkan gelar master dan doktor melalui suatu program akademik yang tepat dan penguatan "ruh" profesi akademik melalui pemberian pelatihan, kompensai dan status yang tepat merupakan sejumlah alternatif yang ditawarkan untuk mengatasi persoalan ini. Hal yang tidak kalah penting adalah memastikan kembali bahwa profesi akademik dapat dilihat oleh para pembuat kebijakan dan masyarakat luas sebagai kunci keberhasilan dari sebuah pendidikan tinggi.

\section{Pengalaman Pelajar}

Pergeseran jumlah, karakteristik, kebutuhan dan ketertarikan mahasiswa telah memberikan dampak yang cukup signifikan terhadap pendidikan tinggi selama 10 tahun terakhir. Kekhawatiran atas tuntutan dan perhatian yang lebih besar kepara mahasiswa, sebagai variabel kunci stakeholder, pada beberapa dekade mendatang akan terus meningkat di seluruh dunia.

Tuntutan tersebut akan mengarahkan, baik langsung maupun tidak langsung, kepada tingkat ukuran, ruang lingkup, kualitas maupun sifat dari suatu pendidikan tinggi. Bagaimana cara yang tepat untuk mengakomodasi dan sekaligus secara efektif dapat memberikan pelayanan yang tepat kepada mahasiswa yang semakin banyak, beragam dan global ini akan menjadi salah satu bahan pertimbangan utama bagi para pembuat kebijakan dan pimpinan lembaga untuk menentukan langkah-langkah strategis di masa mendatang.

${ }^{19}$ Ibid., 89 


\section{Pengajaran, Pembelajaran, dan Penilaian}

Momentum perubahan dan pergeseran paradigma pendidikan tinggi pada kurun satu dekade terakhir telah membawa serta perubahan besar terhadap pendekatan dalam proses pengajaran, pembelajaran dan penilaian. Tantangan-tantangan yang muncul dari pergeseran ini turut berdampak pada penciptaan perubahan-perubahan sistem kebijakan pendidikan, kelembagaan, dan disiplin keilmuan secara signifikan. Privatisasi, massifikasi dan komodifikasi akan turut pula mendorong peningkatan kebutuhan suatu universitas untuk memprioritaskan sektor pengajaran, pembelajaran dan penilaian.

\section{Teknologi Informasi dan Komunikasi dan Pendidikan Jarak Jauh}

Teknologi Informasi dan Komunikasi (TIK) dan pendidikan jarak jauh (distance education) merupakan dua hal yang berbeda, akan tetapi keterkaitan antar aspek-aspeknya saling berhubungan erat. ICT dan pendidikan jarak jauh telah memainkan peran yang cukup signifikan dalam penentuan dan pembuatan kebijakan pendidikan tinggi selama satu dasawarsa terakhir. Kebutuhan untuk memberikan pelayanan prima kepada populasi yang lebih luas dan beragam melalui cara-cara yang lebih fleksibel, efektif dan bahkan murah telah mendorong perubahan sistem pendidikan tinggi dan lembaga pendidikan tinggi di seluruh dunia.

Internet telah memberikan perubahan besar dan nyata terkait bagaimana ilmu pengetahuan dikomunikasikan. Keberadaan TIK di negara-negara maju telah mempengaruhi dan memperluas secara eksponensial semua dimensi pendidikan tinggi. Surel dan jejaring sosial online telah "menjembatani" terselenggaranya aktivitas kolaborasi akademik dan joint research. Trend jurnal elektronik semakin menyebar dan pada beberapa bidang peranannya semakin subtantif. Jurnal akademik juga telah menggeser penerbit-penerbit lokal yang kemudian mulai beralih ke internet untuk mendistribusikan publikasi mereka.

Gerakan pendidikan terbuka (Opensource education movement) kemudian memanfaatkan momentum ini dengan menyediakan akses gratis bagi siapapun untuk mendapatkan pelatihan, kurikulum dan pendekatan pedagogis lain yang tidak ditemukan pada universitas lokal. Selama beberapa dekade sektor ini didominasi oleh universitas " terbuka” skala global. Indira Gandhi National Open University di India setidaknya telah memiliki 1,8 juta mahasiswa. University of Soth Africa (UNISA) yang mengklaim sebagai institusi pembelajaran jarak jauh di Benua Afrika telah memiliki sekitar 250 ribu mahasiswa. African Virtual University yang menyelenggarakan pendidikan lintas negara dan bahasa telah menyelenggarakan pendidikan jarak jauh pada lebih dari 27 negara. ${ }^{20}$

${ }^{20}$ Ibid.,129-135 
Daya tarik dari pendidikan jarak jauh ini adalah disebabkan kemampuan untuk mengakomodasi kebutuhan berbagai peserta didik - orang-orang yang berada jauh dari pusat-pusat pendidikan, sedang bekerja, ibu rumah tangga, ataupun narapidana. Meskipun demikian, resiko dan tantangan dari model pendidikan jarak jauh ini sangatlah besar, namun yang paling utama adalah berkaitan dengan jaminan kualitas dari penyelenggarannya.

\section{Penelitian}

Fungsi penelitian terus mengalami perkembangan secara signifikan. Penelitian akhir-akhir telah diakui sebagai peran sosial yang penting dari sebuah universitas. Bidang kajian penelitian tidak hanya terbatas pada wialayah-wialyah kajian keilmuan tradisional, akan tetapi juga pada wilayah-wilayah interdisipliner.

Bagi sebagian pihak, aktivitas pendanaan dan pelaksanaan kegiatan penelitian merupakan sumber dari status dan prestis internasional. Akan tetapi, dana penelitian saat ini cenderung terkonsentasi di lembaga-lembaga elit di sejumlah negara, terutama negara-negara kaya. Sejumlah negara, khususnya negara berkembang, terus melakukan proyek ambisius untuk terus mendorong aktivitas dan kualitas penelitian mereka, seperti Cina, Republik Korea, Meksiko, Brasil dan Chili.

Pendanaan aktivitas penelitian, sebagian besar berasal dari pendanaan publik dan pada saat yang bersamaa kerjasama dan keterkaitan antara industri dan universitas (University-Industry Linkage) menjadi semakin umum dan penting. Pola ini kemudian berpotensi untuk memperluas kemungkinan pengembangan pendanaan dan kapasiatas penelitian.

\section{Keterkaitan Universitas-Industri (University-Industry Linkage)}

Cara pandang para pembuat kebijakan pendidikan tinggi pada beberapa tahun terkahir telah mengalami pergeseran. Saat ini - berbeda dari masa yang lalu tatkala pendidikan tinggi hanya dianggap sebagai bagian dari kebijakan sosial - pendidikan tinggi dianggap sebagai komponen penting dari kebijakan ekonomi nasional dan regional. Pada tahun 1980-an awal perubahan paradigma tersebut terjadi di Amerika Serikat, ketika Bay-Dole Act diberlakukan untuk memfasilitasi peranan universitas dalam hal transfer teknologi berbasis paten dan sejumlah program yang dilembagakan untuk memperkuat hubungan antara universitas dan industri pada level negara bagian dan negara. ${ }^{21}$ Saat ini sejumlah negara telah memiliki merik-metrik yang secara eksplisit menjelaskan keterkaitan antara universitas dan ekonomi, seperti Inggris dan Skotlandia,

${ }^{21}$ Ibid., 153 
dan lebih jauh lagi telah menetapkan aliran-aliran pendanaan pemerintah berdasarkan metrik-metrik tersebut.

Globalisasi yang berlangsung telah membuka mata negara-negara di berbagai belahan dunia akan arti penting daya saing pada skala global. Pemerintahan suatu negara semakin bergantung dengan universitas sebagai sebuah jangkar dalam sistem inovasi di negara mereka dan universitas memiliki peranan penting bagi "kelangsungan hidup" mereka menghadapi persaingan global ini, yakni pernanan sebagai knowledge economy. Hal ini berimbas pula pada pola hubungan antara universitas dengan industri. Dengan dukungan kemajuan teknologi, pola hubungan antara universitas dengan industri menjadi lebih intens, terjalin dua arah, dan saling menguntungkan .

\section{PERGESERAN PARADIGMA REFORMASI PENDIDIKAN TINGGI}

Saat ini, kecenderugan peningkatan kualitas pendidikan tidak hanya disandarkan pada perbaikan infrastruktur pendidikan, akan tetapi juga perlu mempertimbangkan kecenderungan-kecenderungan dan isu-isu global, sebagaimana yang telah dikemukakan di atas. Salah satu tujuan pendidikan modern adalah membantu tiap individu untuk melihat peran yang tepat bagi mereka di dunia. Kesadaran sebagai bagian dari masyarakat global juga sangat diperlukan. Di era integrasi global, aktivitas atau tindakan tiap individu akan berdampak bagi orang lain, tanggung jawab terhadap aktivitas-aktivitas tersebut juga akan meluas hingga masyarakat sekitar atau bahkan masyarakat di luar batas-batas negara mereka.

Dampak dari persoalan lingkungan di suatu negara, misalnya, akan terasa di seluruh penjuru dunia, meskipun sumber persoalan tersebut hanya terbatas di area atau wilayah yang kecil. Pemahaman terhadap realitas baru merupakan langkah awal untuk meningkatkan kualias para pelajar. Pendidikan memainkan peran vital untuk mencipatakan pemahaman yang lebih baik terhadap realitasrealitas baru tersebut sejak usia dini.

Selain itu, pemeliharaan dan penguatan pengetahuan lokal dan budaya lokal juga memiliki peranan penting bagi penguatan pendidikan tinggi di suatu negara. Suzanne Grant Lewis, menekankan pentingnya menjaga kemampuan lokal suatu negara untuk mendukung dan mengembangkan pengetahuan, budaya dan bahasa lokal dalam menghadapi induksi homogenisasi kurikulum di era global. ${ }^{22}$

${ }^{22}$ David E. Bloom, "Globalization and Education An Economic Perspective, dalam Globalization: Culture and Education in the New Millennium, ed. Marcelo M Suarez-Orozco dan Qin-Hilliard Desire B. (Berkley - Los Angeles - London: University of California Press, 2004), 73 
Lebih lanjut, Cheng (2005) menambahkan bahwa selain pemahaman akan isu dan kecenderungan global, pendidikan tinggi juga perlu memperhatikan persoalan dimensi lokalisasi dan individualisasi-Cheng kemudian menyebutnya dengan istilah triplization process. Menurutnya, reformasi pendidikan secara berkelanjutan merupakan salah satu kebutuhan yang tidak terelakkan sebagai akibat tantangan lokal dan gloal yang muncul dari arus perubahan lingkungan pendidikan yang cepat, kompleks, ambigu dan menghilangkan batas-batas antar institusi dan sistem pendidikan; dengan memperhatikan tripilization process secara komprehensif, dapat dijadikan sebagai landasan untuk membangun sebuah paradigma baru pendidikan tinggi modern. ${ }^{23}$

\section{Globalisasi}

Globalisasi mengacu pada transfer, adaptasi, dan pengembangan nilai-nilai, pengetahuan, teknologi, dan perilaku norma di negara-negara dan masyarakat di berbagai belahan dunia. Fenomena yang khas dan saling terkait dengan pertumbuhan jaringan global (misalnya internet, e-komunikasi seluruh dunia), transfer global. Semua hal tersebut terwujud dalam jaringan teknologi, ekonomi, sosial, politik, budaya, dan aspek pembelajaran, aliansi internasional dan kompetisi, kerjasama internasional dan pertukaran, desa global, integrasi multikututral, dan penggunaan standar internasional dan benchmark.

Implikasi globalisasi pendidikan harus memaksimalkan relevansi pendidikan untuk pembangunan global dan penyatuan intelektual sumber daya, dukungan dan inisiatif dari berbagai belahan dunia dalam pengembangan pendidikan.

\section{Lokalisasi}

Lokalisasi mengacu pada transfer, adaptasi, dan pengembangan nilainilai yang terkait, pengetahuan, teknologi, dan norma-norma perilaku dari/ ke konteks lokal. Beberapa karakteristik dan contoh lokalisasi adalah sebagai berikut: jaringan lokal, adaptasi eksternal teknologi, ekonomi, sosial, politik, budaya, dan pembelajaran inisiatif untuk masyarakat lokal, desentralisasi kepada masyarakat lokal, pengembangan budaya asli, keterlibatan masyarakat lokal, kerjasama antar lembaga, dan dukungan masyarakat; relevansi dan legitimasi; dan pemenuhan kebutuhan berbasis komunitas, norma-norma dan etos sosial masyarakat lokal.

${ }^{23}$ Yin Cheong Cheng, New Paradigm for Re-engineering Education Globalization, Localization and Individualization (Netherland: Springer, 2005) , 25. 
Implikasi dari lokalisasi untuk reformasi pendidikan adalah memaksimalkan relevansi pendidikan dengan pembangunan daerah dan membawa dukungan masyarakat dan sumber daya, kemitraan dan kolaborasi lokal dalam setiap aspek penyelenggaraan pendidikan. Beberapa contoh praktik lokalisasi termasuk keterlibatan masyarakat dalam pendidikan, privatisasi dalam pendidikan, kolaborasi publik dalam kelembagaan, jaminan institusional akuntabilitas; pelaksanaan otonomi kelembagaan berdasarkan manajemen dan kurikulum berbasis masyarakat

\section{Individualisasi}

Individualisasi mengacu pada transfer, adaptasi, dan pengembangan terkait nilai-nilai, pengetahuan, teknologi, dan norma-norma perilaku untuk memenuhi individu kebutuhan dan karakteristik. Individualisasi untuk proses pembangunan manusia didasarkan pada teori-teori motivasi dan kebutuhan manusia.

Beberapa contoh individualisasi dalam pendidikan adalah penyediaan jasa individual, penekanan pada potensi diri setiap peserta didik, promosi atas inisiatif dan kreativitas pesera didik, dan dorongan untuk aktualisasi diri. Implikasi utama dari individualisasi dalam pendidikan adalah untuk memaksimalkan motivasi, inisiatif, dan kreativitas peserta didik dan pendidik dalam aktivitas pembelajaran melalui langkah-langkah seperti menerapkan program pendidikan individu; perancangan desai pembelajaran individu; mendorong siswa untuk pebelajar mandiri, aktualisasi diri, dan penginisiasi, memenuhi kebutuhan khusus individu; dan pengembangan kontekstualisasi kecerdasan majemuk (mulitiple intelligence) peserta didik. 


\section{Tabel 3. Implikasi Tripilization terhadap Pendidikan}

\begin{tabular}{|c|c|c|}
\hline Triplization & Conceptions and Characteristics & Implications for Education \\
\hline Globalization & $\begin{array}{l}\text { Transfer, adaptation, and development } \\
\text { of values, knowledge, technology and } \\
\text { behavioral norms across countries } \\
\text { and societies in different parts of the } \\
\text { world: } \\
\text { - Global Networking } \\
\text { - Technological, Economic, Social, } \\
\text { Political, Cultural, and Learning } \\
\text { Globalization } \\
\text { - Global Growth of Internet } \\
\text { - International Alliances and } \\
\text { Competitions } \\
\text { - International Collaboration \& } \\
\text { Exchange } \\
\text { - Global Village } \\
\text { - Multi-cultural Integration } \\
\text { International Standards and } \\
\text { Benchmarks }\end{array}$ & $\begin{array}{l}\text { To maximize the education relevance to } \\
\text { global development and pool up best } \\
\text { intellectual resources, support, and } \\
\text { initiatives from different parts of the world } \\
\text { for learning, teaching and schooling: e.g. } \\
\text { - Web-based Learning } \\
\text { - International Visit/lmmersion Program } \\
\text { - International Exchange Program } \\
\text { - Learning from Internet } \\
\text { - International Partnership in Teaching } \\
\text { and Learning at group, class, and } \\
\text { individual levels } \\
\text { - Interactions and Sharing through } \\
\text { Video-Conferencing across Countries, } \\
\text { Communities, Institutions, and } \\
\text { Individuals } \\
\text { - Curriculum Content on Technological, } \\
\text { Economic, Social, Political, Cultural, } \\
\text { and Learning Globalizations }\end{array}$ \\
\hline Localization & $\begin{array}{l}\text { Transfer, adaptation, and development } \\
\text { of related values, knowledge, } \\
\text { technology, and behavioral norms } \\
\text { fromito the local contexts: } \\
\text { - Local Networking } \\
\text { - Technological, Economic, Social, } \\
\text { Political, Cultural, and Learning } \\
\text { Localization } \\
\text { - Decentralization to the Local Site } \\
\text { Level } \\
\text { - Indigenous Culture } \\
\text { - Community Needs and Expectations } \\
\text { - Local Involvement, Collaboration and } \\
\text { Support } \\
\text { - Local Relevance and Legitimacy } \\
\text { - Community-based Needs and } \\
\text { Characteristics } \\
\text { Social Norms and Ethos }\end{array}$ & $\begin{array}{l}\text { To maximize the education relevance to } \\
\text { local developments and bring in community } \\
\text { support and resources, local partnership, } \\
\text { and collaboration in learning, teaching } \\
\text { and schooling: e.g. } \\
\text { - Community Involvement } \\
\text { - Public-Institutional Collaboration } \\
\text { - Institutional-based Management \& } \\
\text { Accountability/School-based } \\
\text { Management } \\
\text { - Inter-institutional Collaboration } \\
\text { - Community-related Curriculum } \\
\text { - Curriculum Content on Technological, } \\
\text { Economic, Social, Political, Cultural, } \\
\text { and Learning Localizations }\end{array}$ \\
\hline Individualization & $\begin{array}{l}\text { Transfer, adaptation, and development of } \\
\text { related external values, knowledge, } \\
\text { technology, and behavioral norms to meet } \\
\text { individual needs and characteristics: } \\
\text { - Individualized Services } \\
\text { - Development of Human Potential in } \\
\text { Technological, Economic, Social, } \\
\text { Political, Cultural and Learning } \\
\text { Aspects } \\
\text { - Human Initiative and Creativity } \\
\text { - Self-actualization } \\
\text { - Self-managing and Self-governing } \\
\text { - Special Needs }\end{array}$ & $\begin{array}{l}\text { To maximize motivation, human initiative, } \\
\text { and creativity in learning, teaching and } \\
\text { schooling: } \theta .9 \text {. } \\
\text { - Individualized Educational Programs } \\
\text { - Individualized Learning Targets, } \\
\text { - Methods, and Progress Schedules } \\
\text { - Self Lifelong Learning, Self } \\
\text { Actualizing, and Self Initiative } \\
\text { - Self Managing Students and Teachers } \\
\text { - Meeting Special Needs } \\
\text { - Development of Contextualized } \\
\text { Multiple Intelligences }\end{array}$ \\
\hline
\end{tabular}

Sebagai lembaga pendidikan yang memiliki peranan besar dalam meningkatkan kehidupan intelektual, kultural dan dan sosial bangsa Indonesia, Pendidikan Tinggi Kegamaan Islam tidak dapat diabaikan peran dan fungsinya dalam upaya peningkatan mutu pendidikan nasional. Meskipun demikian, jika tanpa adanya internal conciousness for improvement, maka mustahil bagi PTKI di Indonesia dapat melanjutkan kiprah strategisnya dalam persaingan global di masa mendatang karena abad 21 ditandai dengan mega-kompetisi, yakni masyarakat yang mampu berkompetisi dengan baik dan memiliki kesadaran global (global consiousness) atas berbagai kecenderungan global dan pergeseran paradigma global reformasi pendidikan. 
Sebuah institusi yang menginginkan untuk memperoleh hasil kinerja yang lebih baik, akan terlibat secara obyektif dalam upaya evaluasi dan penilaian terhadap kekuatan dan lingkungan kebijakan mereka dalam rangka perbaikan kinerja, melakukan penguatan pada tujuan institusi, dan menerjemahkan tujuan tersebut dalam sebuah perencanaan pembaharuan secara efektif.

Salmi mencontohkan, dari hasil penelitiannya di University of São Paulo, ditemukan bahwa lembaga yang telah merasa "berpuas diri" dengan visi-misi mereka atau tidak memiliki visi ambisius masa depan yang lebih baik, atau terus beroperasi dengan paradigma "konvensional", berakhir dengan kesenjangan kinerja bila dibandingkan dengan para pesaing-pesaing nasional maupun internasional mereka. ${ }^{24}$

Donoghue and Kennerley dalam Salmi menggambarkan perbedaan pola kinerja institusi antara lembaga-lembaga yang berkinginan untuk memperoleh hasil kinerja yang lebih baik dengan lembaga-lembaga yang tidak ambisisus atau memilih untuk bertahan dengan gaya "konvensional" tersebut dalam sebuah bagan berikut. ${ }^{25}$

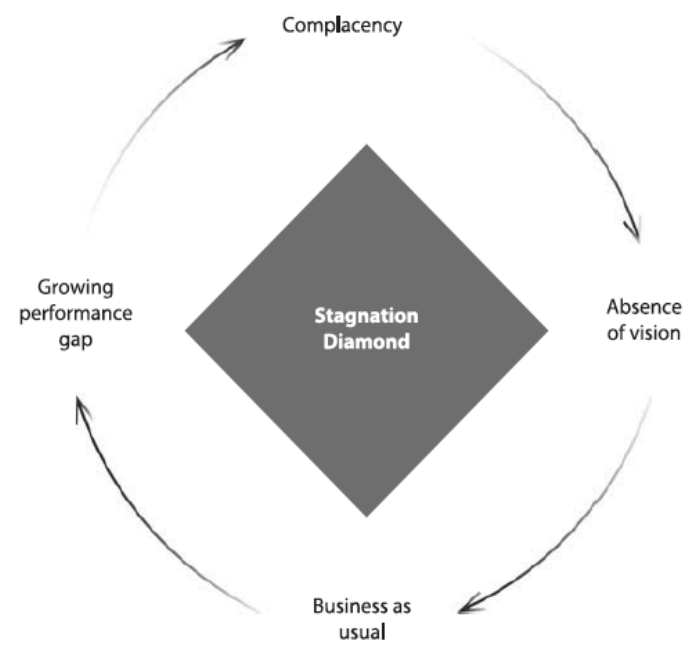

Gambar 2. Pola Kinerja Institusi Lembaga yang tidak ambisi

${ }^{24}$ Jamil Salmi, The Challenge of Establishing World-Class Universities, (Washington: The World Bank, 2009), 54

${ }^{25}$ Ibid., 53 


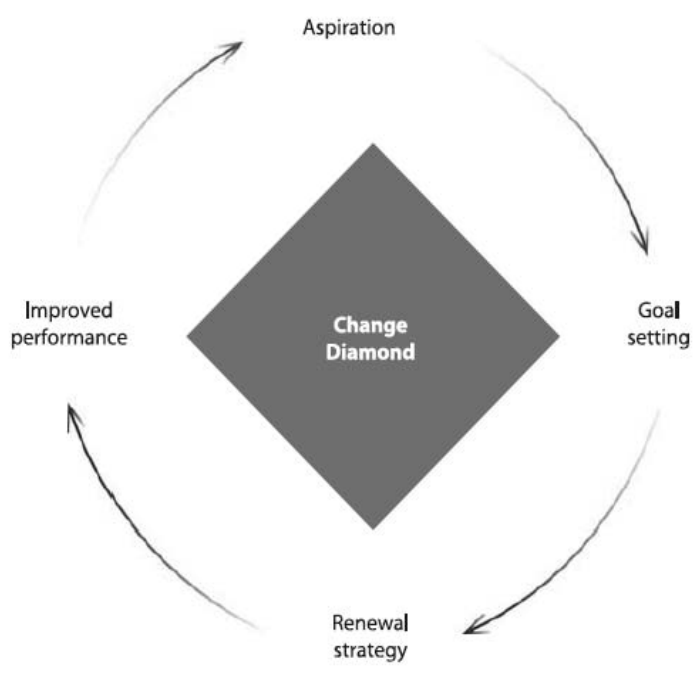

Gambar 3. Pola Kinerja Institusi Lembaga yang Menginginkan Perubahan "Change Diamon"

Sumber: The Challenge of Establishing World-Class Universities, 2009

\section{KESIMPULAN}

Kecenderungan global yang melanda perguruan tinggi di seluruh penjuru dunia, telah mengakibatkan pergeseran paradigma reformasi pendidikan tinggi. Pergeseran paradigma tersebut tentu memberikan pengaruh besar terhadap penyelenggaran pendidikan di lembaga-lembaga pendidikan tinggi di seluruh dunia, termasuk lembaga-lembaga pendidikan Pendidikan Tinggi Keagamaan Islam di Indonesia. Tanpa adanya internal conciousness for improvement, maka mustahil bagi PTKI di Indonesia dapat melanjutkan kiprah strategisnya dalam persaingan global, karena abad 21 menuntut kesadaran global sebuah institusi pendidikan tinggi atas berbagai isu dan kecenderungan global dan pergeseran paradigma global reformasi pendidikan jika ingin tetap survive di era megakompetisi ini. 


\section{DAFTAR PUSTAKA}

Altbach, Philip G., et al , 2009, Higher Education; Tracking an Academic Revolution (A Report Prepare For UNESCO 2009 World Conference on Higher Education), Paris, UNESCO.

Bidang Pendayagunaan dan Pelayanan Data dan Statistik Pendidikan, 2013, APK/APM (Angka Partisipasi Kasar/Angka Partisipasi Murni) Tahun 2012/2013, Jakarta: Pusat Data dan Statistik Pendidikan, Kemdikbud.

Bloom, David E. , 2004, "Globalization and Education An Economic Perspective, dalam Globalization: Culture and Education in the New Millennium, ed. Marcelo M Suarez-Orozco dan Qin-Hilliard Desire B., Berkley - Los Angeles - London: University of California Press.

Maringe. F, 2010, "The Meanings of Globalization and Internationalization in HE: Findings from a World Survey" dalam Globalization and Internationalization in Higher Education: Theoretical, Strategic and Management Perspectives,ed. Maringe et al., New Yok: Continuum International Publishing Group

J. Knight, 1999, "Internationalisation of Higher Education.” dalam Organisation for Economic Cooperation and Development, Quality and Internationalisation in Higher Education, Paris: OECD

Jamil Salmi, 2009, The Challenge of Establishing World-Class Universities, Washington: The World Bank.

UNESCO, 1998, Higher Education in the Treenty-First Century: Vision and Action, Paris: UNESCO

van Ginkel, 2007, H.J.A. and Rodrigues Dias, M.A. Institutional and politicalchallenges of accreditation at the international level. J. Tres (ed.), Higher Education in the World 2007, New York: Palgrave Macmillan.

Cheng, Yin Cheong, 2005, New Paradigm for Re-engineering Education Globalization, Localization and Individualization, Netherland: Springer.

“10 Universitas Terbaik”, Edisi Khusus Perguruan Tinggi/Infografik, Majalah Tempo edisi 20 Mei 2007.

"Peringkat PTN", Edisi Jumat, 30 Mei 2008 diakses dari http://nasional. kompas.com/read/2008/05/30/05101132/peringkat.ptn diakses pada 14 November 2014

"Sebaran Lembaga, Fakultas dan Prodi pada PTKIN dan PTAIS", http:// ranking-ptai.info diakses tanggal 10 September 2014 
Gorard, S., Smith, E., May, H.,Thomas, L.,Adnett, N. and Slack, K. 2006. Review of Widening Participation Research: Addressing the Barriers to Participation in Higher Education. Diakses dari: http://www.hefce. ac.uk/pubs/RDreports/2006/rd13_06/pada 1 Mei 2014. 